\title{
ОСОБЛИВОСТІ ЦІННІСНО-СМИСЛОВОЇ СФЕРИ ВІЙСЬКОВОСЛУЖБОВЦІВ 3 РІЗНИМ ДОСВІДОМ УЧАСТІ В БОЙОВИХ ДІЯХ
}

\author{
Лариса Журавльова \\ доктор психологічних наук, професор, \\ завідувач кафедри психології розвитку та консультування \\ Житомирський державний університет імені Івана Франка \\ 10008, Україна, м. Житомир, вул. Велика Бердичівська, 40 \\ 1pz2008@ukr.net, https://orcid.org/0000-0003-4020-7279
}

\section{Катерина Кротюк}

аспірантка кафедри психології розвитку та консультування

Житомирський державний університет імені Івана Франка 10008, Україна, м. Житомир, вул. Велика Бердичівська, 40 demkatty28@ukr.net, https://orcid.org/0000-0003-3237-6494

\section{Анотація}

У статті обгрунтовується актуальність і доцільність дослідження ціннісно-смислової сфери військовослужбовців. Метою дослідження $\epsilon$ вивчення впливу досвіду участі військовослужбовців у бойових діях на їх ціннісно-смислову сферу. Аналізуються основні підходи до проблеми ціннісно-смислової сфери особистості у сучасній психології, зокрема, іiі зміни внаслідок виконання професійних обов'язків у галузі військової діяльності. Її специфіка пов'язана $з$ небезпекою та прийняттям ризикових рішень, що зумовлює переосмислення життєвих цінностей. Тому було сформульовано припущення про деструктивний вплив досвіду участі в бойових діях на ціннісно-смислову сферу військовослужбовців. Подано результати емпіричного дослідження смисложиттєвих орієнтацій військовослужбовців (базового компонента ціннісно-смислової сфери); здійснено порівняльний аналіз їх показників у респондентів із різним досвідом перебування в зоні Операції об'єднаних сил (ООС). Встановлено, що середні показники та відсоткове зіставлення рівнів значущості смисложиттєвих орієнтацій військовослужбовців експериментальної (учасники бойових дій у зоні ООС) і контрольної (не перебували в зоні OOC) груп не мають статистично значущих відмінностей, проте мають деяку специфіку. Проаналізовано, що серед учасників бойових дій, на противагу тим, хто не має такого досвіду, достовірно більша кількість людей є задоволеними власним життям і здатні контролювати його залежно від певних обставин. Виявлено негативний вплив хронологічного (онтогенетичного) віку досліджуваних, які мають досвід перебування в ООС, на якість і показники їх смисложиттєвих орієнтацій. Ціннісні орієнтації учасників бойових дій загалом $є$ більш диференційованими за їх значущістю й осмисленістю, порівняно з військовослужбовцями, які не перебували в зоні проведення ООС. Достовірно більша кількість респондентів із бойовим досвідом, порівняно з тими, хто його не має, виявляє полярність в осмисленні життєвих цінностей: дуже глибоко осмислює смисложиттєві орієнтації чи втрачає у них сенс. 
Ключові слова: ціннісно-смислова сфера, цінності, смисли, смисложиттєві орієнтації, військова сфера, військова діяльність, Операція об’єднаних сил (ООС).

\section{Вступ}

Військова сфера - це область життєдіяльності держави, яка об'єктивно необхідна для забезпечення iї динамічного, сталого та безпечного розвитку. Професійна діяльність військовослужбовців відбувається в умовах, пов'язаних з певним ризиком для життя та здоров'я. Участь військовослужбовців у бойових діях призводить до помітних змін в їх свідомості, що мають травматичний характер. За результатами досліджень військових медиків і психологів (Ягупов, 2004; Hogg, 2003), після повернення до мирного життя у військовослужбовців спостерігається криза ідентичності, тобто втрата цілісного сприймання себе, власної соціальної ролі, ціннісного та смислового сприймання світу.

Незважаючи на інтенсифікацію досліджень у військовій психології, недостатньо вивченою залишається проблема ціннісної сфери військовослужбовців, які перебували у зоні проведення бойових дій.

Значний дослідницький доробок психологів зумовив існування багатьох тлумачень структури та детермінації ціннісно-смислової сфери особистості (Виговський, 2012; Frank1, 2004). На їх думку, ціннісно-смислова сфера є смисловим регулятором поведінки i діяльності людини, що формується в процесі її соціалізації та зазнає змін упродовж життя.

Завдяки численним психологічним дослідженням (Ананьев, 2016; Рубинштейн, 2012; Park \& Guay, 2009; Parks-Leduc, 2014), цінності визначаються як одне 3 найважливіших особистісних утворень, що репрезентує свідоме ставлення людини до соціальної діяльності, визначає іiі мотивацію та подальшу життєдіяльність. Цінності - це не лише форма відношення об'єкта і суб'єкта, а саме свідоме відтворення суб'єктом ціннісних властивостей об'єкта.

Нерозривно взаємопов'язаними з цінностями є сенс життя і смисли. Саме ця проблема залежить від конкретної культурно-історичної доби, соціальних умов розвитку особистості (Журавльова \& Мужанова, 2019). Сенс життя також може полягати в суб'єктивній оцінці власних дій у минулому та побудові планів щодо майбутнього.

Визначення понять «сенс життя» та «смисл» є складними, оскільки кожна людина може вкладати в їх зміст власне значення. Сенс життя визначається через його стратегічну мету, яка є цілком усвідомлюваною і довготривалою. В процесі пошуку сенсу життя людина переважно керується совістю: інтуїтивною здатністю до вибору правильного рішення (Frankl, 2004).

Результатом визначення людиною цінностей i сенсу життя є смисли. Вони утверджуються в процесі життя залежно від діяльності людини, іiї ставлення до оточення (Выготский, 2005; Леонтьев, 2007). Смисл утворюється в процесі оцінювання людиною себе та навколишнього світу, презентує відношення між ними. Тому, цінності та смисли інтеріоризуються, тобто стають внутрішньою характеристикою людини. Для їх закріплення потрібні: позитивний вплив соціально-психологічних чинників, схвалення i підтримка. Одним із соціально-психологічних чинників цих феноменів $\epsilon$ професійна діяльність (Журавльова \& Матюшенко, 2009).

Відповідно до загальноприйнятого положення про вплив професійної діяльності на розвиток цінностей особистості, умови військової служби визначають низку особливостей 
у структурі їх діяльності, які, в свою чергу, впливають на смисложиттєві орієнтації військовослужбовців. Основними складовими цієї структури є професійна мотивація, професійний досвід, психічні функції та властивості (Ягупов, 2004).

Водночас чинники ціннісно-смислової сфери військовослужбовців здійснюють вплив на всіх етапах професіоналізації. Проблема ціннісного (зокрема, морального) вибору постає по-різному, залежно від етапу й рівня розвитку особистості, конкретніше від рівня сформованості й усталеності системи прийнятих нею ціннісних орієнтирів. Тією мірою, якою така усталеність ще не $є$ досягнутою (або втраченою під тиском тих чи інших обставин), для особистості $€$ актуальним здійснення постійних численних виборів (застосувати або не застосувати зброю).

Високорозвинена особистість усвідомлює сенс життя і глибоко віддана власним цінностям: «Для людини, яка перейнялася найвищою духовною цінністю, вибір перестає бути нагальною проблемою, бо ця людина вже раз і назавжди обрала свій життєвий шлях, знайшла себе, свою основну спрямованість, виявила джерело осмислення буття та якусь життєву істину й тим самим зробила наперед (не в деталях, а у принципі, не 3 зовнішнього, а з внутрішнього ціннісно-смислового боку) всі можливі наступні вибори» (Василюк, 1984: 126). Ці слова Ф. Василюка, хоча й заслуговують на підтримку, та все ж відтворюють дійсність дещо спрощено. Реалії життя можуть ставити й високорозвинену особистість перед необхідністю щоденного вибору, а саме - між різними значущими для неї цінностями (громадянськими, військово-професійними, сімейними, особистісними тощо). Найбільшою складністю є прийняття важливих рішень в умовах небезпеки, зокрема, в умовах військової діяльності.

Специфічність військової діяльності полягає в тому, що, з одного боку - це складне соціальне явище, яке є частиною суспільного життя; а, з іншого боку, військова діяльність має свої особливості в проявах моральності. Такою особливістю є постійна готовність і моральна здатність здійснювати збройне насильство на користь захисту суспільства, досягати поставлених керівництвом цілей, навіть ціною самопожертви (Dixon, 2012; Thomas, 2006).

Військова діяльність, з одного боку, має всі характеристики будь-якої праці, а 3 іншого - може поділятися на неруйнівну (в умовах мирного часу), і руйнівну (в умовах війни) (Atkinson, 2003; Freud, 2013). Причому остання, залежно від соціальної спрямованості, цілей та інтересів ऑiі суб'єктів, може виконувати як позитивну, так і негативну роль у ціннісно-смисловій сфері особистості військовослужбовця. Вона призводить до постійного переосмислення життєвих цінностей, оскільки ії специфіка є небезпечною та часто кризовою для особистості.

Смислові утворення, що $є$ відкритою системою особистісних смислів, постійно змінюються, вбираючи в себе нові, набуті смисли (Леонтьев, 2007). Внаслідок участі у бойових діях, яка є кризовою ситуацією, відбувається трансформація смислової структури особистості: людина намагається знайти сенс власної діяльності як для його розуміння, так і для подальшого життя. Військовослужбовець у процесі власної діяльності може переживати смислові конфлікти, але може і відкрити нові смисли буття, спрямовані на розвиток і зростання його особистості. Така перебудова внутрішнього світу, безумовно, призводить до певних втрат, проте і відкриває для людини нові горизонти особистісного зростання (Lawrence, 2017; Murray, 2002). 
Незважаючи на значну кількість праць, присвячених дослідженню ціннісносмислової сфери особистості (Виговський, 2012; Журавльова \& Матюшенко, 2009; Журавльова \& Мужанова, 2019; Леонтьев, 2007), недостатньо вивченим є питання, які саме цінності та смисли переважають у військовослужбовців-учасників бойових дій і чим вони відрізняються від військовослужбовців, які не мають такого досвіду.

Мета дослідження: емпірично вивчити вплив хронологічного віку і досвіду участі військовослужбовців у бойових діях на їх ціннісно-смислову сферу. Гіпотеза дослідження полягає у деструктивному впливі досвіду участі в бойових діях на ціннісно-смислову сферу військовослужбовців. Завдання дослідження: 1) вивчити особливості смисложиттєвих орієнтацій (базового компонента ціннісно-смислової сфери) військовослужбовців із різним досвідом перебування в Операції об'єднаних сил; 2) дослідити вплив хронологічного віку на розвиток смисложиттєвих орієнтацій військовослужбовців.

\section{Методи дослідження}

Для досягнення мети дослідницької роботи застосовувалися психодіагностичні та статистичні методи. 3 метою дослідження базового компонента ціннісно-смислової сфери особистості - смисложиттєвих орієнтацій (Виговський, 2012) було застосовано методику «Тест смисложиттєвих орієнтацій (СЖО)» Д. Леонтьєва (Леонтьев, 2000), яка складається 3 таких шкал: «Цілі», «Процес», «Результат», «Локус-контролю - Я», «Локус-контролю життя» та «Осмисленість життя». Також використано такі статистичні методи: t-критерій Стьюдента для незалежних вибірок з метою статистичної перевірки відмінностей між складовими ціннісно-смислової сфери контрольної (військовослужбовці, які не мають досвіду участі в зоні Операції об'єднаних сил (ООС)) та експериментальної (військовослужбовці-учасники бойових дій ООС) груп; метод кутового перетворення Фішера та рангову кореляцію Спірмена.

Дослідження проводилось у військовій частині Житомирського району. Загальна вибірка складає 70 військовослужбовців-чоловіків: 35 з яких мали досвід участі в Операції об’єднаних сил (експериментальна група), 35 - не мали (контрольна група).

Етапи емпіричного дослідження:

1. Діагностика та здійснення порівняльного аналізу показників смисложиттєвих орієнтацій військовослужбовців-учасників бойових дій i тих, які не були в зоні проведення ООС.

2. Диференціація рівнів прояву (від високого до низького) смисложиттєвих орієнтацій військовослужбовців, які перебували/не перебували в зоні ООС.

3. Дослідження впливу хронологічного віку військовослужбовців на розвиток складових їх ціннісно-смислової сфери.

\section{Результати та дискусії}

Емпіричне дослідження військовослужбовців-учасників бойових дій і тих, хто не був у зоні проведення Операції об'єднаних сил виявило, що їх показники смисложиттєвих орієнтацій не мають відхилень від стандартної норми. Проте, у респондентів обох груп середні показники $є$ нижчими середніх значень стандартної норми, крім шкали 
«Результат» в учасників бойових дій і «Локус-контролю -Я» у військовослужбовців, які не мають такого досвіду (див. рис. 1).

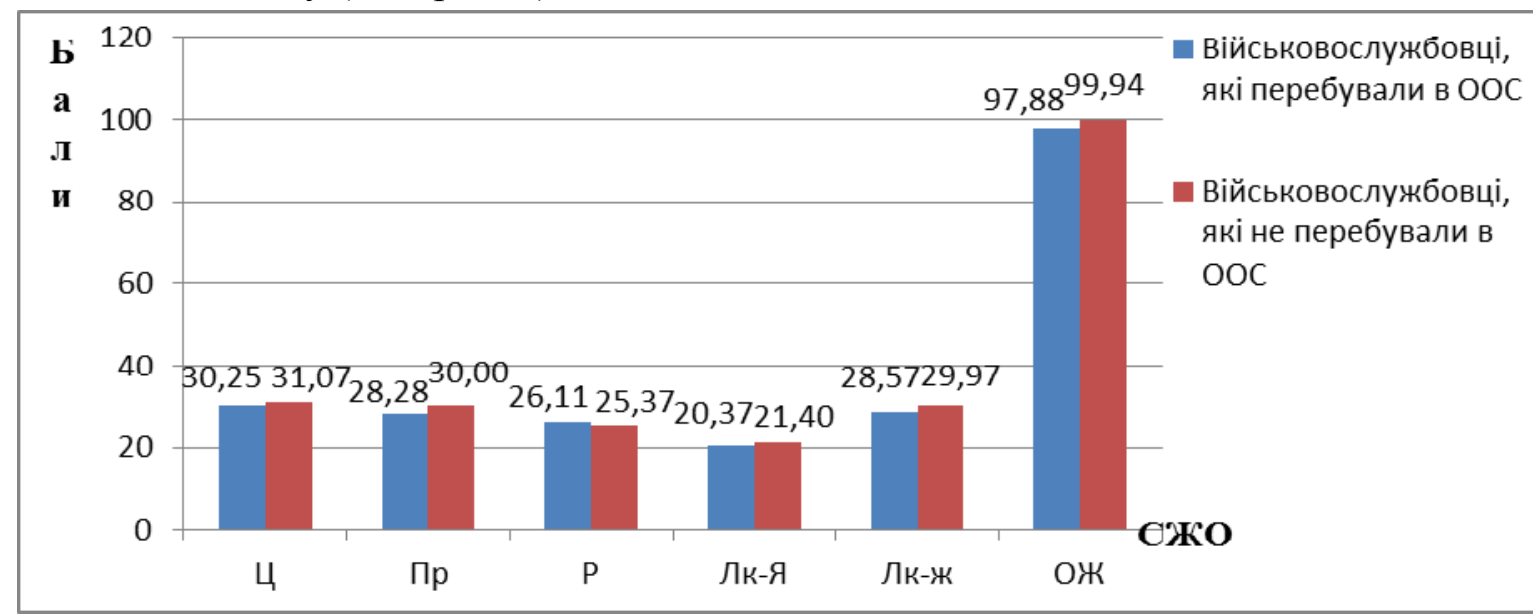

Рис. 1. Середні показники смисложиттєвих оріснтацій військовослужбовців, які перебували/не перебували в зоні ООС

Примітки: СЖО - смисложиттєві орієнтащії; Ц - Цілі; Пр - Прочес; P - Результат; Лк-Я - Локус-контролю - Я; Лк-життя - Локус-контролю - життя; ОЖ-осмисленість життя.

Як видно з рис. 1, військовослужбовці, які не перебували в зоні проведення ООС, порівняно з військовослужбовцями-учасниками бойових дій, мають вищі показники за усіма шкалами смисложиттєвих орієнтацій, крім шкали «Результат». Це свідчить про те, що досліджувані контрольної групи, порівняно з досліджуваними експериментальної, більшою мірою $\epsilon$ цілеспрямованими, сприймають життя насиченим, контролюють його та чітко визначають плани на майбутнє. Учасники бойових дій переважно живуть сьогоднішнім днем, рідше контролюють власне життя, вважають, що свобода вибору є ілюзорною. Найвищі показники учасників ООС за шкалою «Результат», порівняно 3 досить низькими решти шкал, характеризує їх як таких людей, що доживають останні дні власного життя, для них, уже все в минулому, проте воно здатне надати сенсу залишку цього життя. Очевидно, такі результати зумовлені тим, що наразі їх військова служба передбачає готовність у будь-який момент пожертвувати власним життям. Прагнення до самореалізації $€$ важливим фактором їх мотивації до діяльності та пріоритетом у формуванні цінностей.

Для більш детального змістовного аналізу показників смисложиттєвих орієнтацій військовослужбовців було здійснено їх диференціацію від високого до низького рівнів проявів (див. табл. 1).

Як видно 3 табл. 1, за шкалою «Цілі» однаковою мірою, незалежно від досвіду участі в бойових діях, респонденти обох груп мають середній і високий рівні розвитку цілеспрямованості (по 97,1\% військовослужбовців-учасників бойових дій і тих, хто не брав участі в ООС). Вони живуть не лише теперішніми чи минулими подіями, а намагаються будувати перспективні плани. Більша половина досліджуваних має показники цілеспрямованості, які відповідають середньому рівню іiі розвитку. Третина респондентів в обох групах є високо цілеспрямованими особами, проте, за певних обставин їх плани можуть не підкріплюватись особистою відповідальністю за реалізацію. 
Низькі показники мають лише по 2,9\% досліджуваних контрольної й експериментальної груп, які свідчать про відсутність у них планів на майбутнє та їх осмисленості.

Таблиия 1

Рівні прояву показників смисложиттєвих орієнтацій військовослужбовців, які перебували/не перебували в зоні ООС (\%)

\begin{tabular}{|c|c|c|c|}
\hline Шкала & Рівень & $\begin{array}{l}\text { Військовослужбовці- } \\
\text { учасники бойових дій }\end{array}$ & $\begin{array}{c}\text { Військовослужбовці, які не } \\
\text { перебували в зоні } \\
\text { проведення ООС } \\
\end{array}$ \\
\hline \multirow{3}{*}{ «Цілі» } & Високий & 37,1 & 28,6 \\
\hline & Середній & 60,0 & 68,5 \\
\hline & Низький & 2,9 & 2,9 \\
\hline \multirow{3}{*}{ «Процес» } & Високий & 34,3 & 28,6 \\
\hline & Середній & 57,1 & 68,5 \\
\hline & Низький & 8,6 & 2,9 \\
\hline \multirow{3}{*}{ «Результат» } & Високий & 20,0 & 14,3 \\
\hline & Середній & 71,4 & 74,3 \\
\hline & Низький & 8,6 & 11,4 \\
\hline \multirow{3}{*}{$\begin{array}{l}\text { «Локус- } \\
\text { контролю - Я» }\end{array}$} & Високий & 0,0 & 0,0 \\
\hline & Середній & 80,0 & 82,9 \\
\hline & Низький & 20,0 & 17,1 \\
\hline \multirow{3}{*}{$\begin{array}{l}\text { «Локус- } \\
\text { контролю - } \\
\text { життя» } \\
\end{array}$} & Високий & 28,6 & 42,9 \\
\hline & Середній & 68,5 & 48,6 \\
\hline & Низький & 2,9 & 8,5 \\
\hline \multirow{3}{*}{$\begin{array}{l}\text { «Осмисленість } \\
\text { життя» }\end{array}$} & Високий & 28,6 & 17,1 \\
\hline & Середній & 42,8 & 62,9 \\
\hline & Низький & 28,6 & 20 \\
\hline
\end{tabular}

У більшої половини досліджуваних також переважає середній рівень оцінки емоційної насиченості власного життя (шкала «Процес»). Третина респондентів в обох групах мають високі показники за даною шкалою. Вони сприймають життя як насичений процес, сповнений сенсу. Низькі показники має решта обох груп досліджуваних, що репрезентує їх невдоволеність сьогоденним життям, проте повноцінний сенс йому можуть надавати спогади про минуле або націленість на майбутнє. Зауважимо, що серед учасників Операції об'єднаних сил незадоволених власним життям майже втричі більше осіб, порівняно з «тиловиками».

Дещо інший розподіл за рівнями констатовано в оцінці результативності власного життя. Переважна більшість (до 75\%) досліджуваних обох груп має середній рівень задоволеності власною самореалізацією (шкала «Результативність життя»). Вони адекватно оцінюють прожиту частину життя. Високі бали за цією шкалою має лише кожен п’ятий досліджуваний експериментальної та контрольної груп. Вони виявляють високу задоволеність прожитим життям і досягнутими звершеннями. Низькі показники має кожен десятий респондент з різним досвідом перебування в зоні ООС, що свідчить про повну їх невдоволеність прожитою частиною життя. Чинниками, що зумовлюють такий результат, можуть бути нездійснені плани та цілі, фатальні помилки у минулому. Проте, переважна більшість військовослужбовців задоволена прийнятим свого часу рішенням служити в Українській армії. 
Принципово відрізняються від інших результати за шкалою «Локус-контролю - Я» (Я-господар життя), оскільки високих показників не має жоден з військовослужбовців обох груп досліджуваних. П'ята частина респондентів контрольної та експериментальної груп має низькі показники за цією шкалою. Вони не вірять у власні сили та не здатні контролювати життєві події. Очевидно, чинниками таких результатів є відсутність можливості приймати самостійні рішення, необхідність виконувати розпорядження керівництва, невизначеність їх життєвої ситуації. У респондентів обох груп переважають середні показники осмисленості даної складової ціннісно-смислової сфери. Вони намагаються будувати власне життя у відповідності з поставленими цілями, враховуючи особливості військової служби.

За субшкалою «Локус-контролю - життя» високі показники мають 28,6\% військовослужбовців-учасників бойових дій і 42,9\% військовослужбовців без такого досвіду. Ці чоловіки переконані, що людині дано контролювати власне життя, вільно ухвалювати і втілювати рішення. Середні бали отримала половина досліджуваних контрольної та експериментальної груп. Такі результати свідчать про їх прагнення до контролю власних дій і планів щодо майбутнього. Решта респондентів обох груп виявляють фаталізм, переконані в тому, що свобода вибору - ілюзія.

Респонденти обох груп осмислюють власне життя на середньому рівні (шкала «Осмисленість життя»). Військовослужбовці, незалежно від досвіду участі в бойових діях, частково усвідомлюють власне життя через внутрішні переконання, ставлення до себе та майбутнього. Інша частина досліджуваних експериментальної та контрольної груп мають кардинально різну осмисленість життя. Тобто, або глибоко його осмислюють, адекватно розуміючи вплив власних дій і прийняття важливих рішень на майбутнє, або зовсім втрачають у ньому сенс. Низька осмисленість життя респондентів обох груп може виявлятись у негативній рефлексії набутого досвіду, що деструктивно впливає на прийняття рішень і планування майбутнього, в неадекватному усвідомленні подій, що в подальшому може зумовити згубні наслідки для життя і здоров'я військовослужбовця та його побратимів.

Варто зазначити, що середні показники та відсоткове зіставлення рівнів значущості смисложиттєвих орієнтацій військовослужбовців, які перебували/не перебували в зоні OOC не $є$ кардинально відмінними за своїм характером, проте вони мають деяку специфіку. В результаті застосування методів статистичної обробки даних визначено, що відмінності між усіма показниками смисложиттєвих орієнтацій у респондентів обох груп не $\epsilon$ статистично значущими («Цілі»: $\mathrm{t}=-040, \mathrm{p} \leq 0,69$; «Процес»: $\mathrm{t}=-0,53, \mathrm{p} \leq 0,60$; «Результат»: $\mathrm{t}=0,44, \mathrm{p} \leq 0,66$; «Локус-контролю - Я» та «Локус-контролю - життя»: $\mathrm{t}=-0,72, \mathrm{p} \leq 0,47 ;$ «Осмисленість життя»: $\mathrm{t}=-0,37, \mathrm{p} \leq 0,71)$.

Проте помічено відмінності у розподілі рівнів осмисленості, значущості змістових характеристик трьох смисложиттєвих орієнтацій у респондентів із різним досвідом перебування в зоні ООС. Статистично достовірні відмінності виявлено між обома групами респондентів, що мають середній рівень оцінки емоційної насиченості процесу власного життя (шкала «Процес», $\left.\left(\varphi^{*}=0,03, \mathrm{p} \leq 0,10\right)\right)$ i його загальної осмисленості (шкала «Осмисленість життя», $\left.\left(\varphi^{*}=0,04, \quad \mathrm{p} \leq 0,08\right)\right)$, а також між респондентами експериментальної та контрольної груп, які на високому і середньому рівнях вбачають смисл у керованості життям («Локус-контролю - життя») (відповідно, $\varphi^{*}=0,02, \mathrm{p} \leq 0,10$; 
$\left.\varphi^{*}=0,04, p \leq 0,07\right)$. Тобто, серед учасників бойових дій достовірно більша кількість людей задоволених власним життям, які вважають його цікавим, емоційно насиченим і вірять у те, що здатні контролювати його, управляти ним, відповідно до певних обставин, на противагу тим, хто не був у зоні проведення ООС. Досліджувані контрольної групи більшою мірою, порівняно з респондентами експериментальної групи, є впевненими в тому, що можуть вільно ухвалювати рішення та будувати плани на майбутнє, більше осмислюють власне життя завдяки позитивній рефлексії минулого досвіду. Не виявлено достовірних відмінностей між високими та низькими показниками за шкалами «Процес» (відповідно, $\left.\varphi^{*}=0,004, \mathrm{p} \leq 0,39 ; \varphi^{*}=0,02, \mathrm{p} \leq 0,30\right)$ та «Осмисленість життя» (відповідно, $\left.\varphi^{*}=0,001, \mathrm{p} \leq 0,50 ; \varphi^{*}=0,010, \mathrm{p} \leq 0,29\right)$, низькими за «Локус-контролем - життя» $\left(\varphi^{*}=0,015, \mathrm{p} \leq 0,30\right)$ між обома групами досліджуваних.

Для більш детальної інтерпретації специфіки смисложиттєвих орієнтацій респондентів знаходились кореляційні взаємозв'язки між їх показниками і хронологічним (онтогенетичним) віком. У військовослужбовців-учасників бойових дій зафіксовано достовірні обернено пропорційні взаємозв'язки між показниками віку i всіма смисложиттєвими орієнтаціями: «Цілі» $(\mathrm{r}=-0,45, \rho \leq 0,01)$, «Процес» $(\mathrm{r}=-0,36, \rho \leq 0,03)$, «Результат» $(\mathrm{r}=-0,53, \rho \leq 0,001)$, «Локус-контролю - Я» $(\mathrm{r}=-0,48, \rho \leq 0,004)$, «Локусконтролю - життя» $(\mathrm{r}=-0,45, \rho \leq 0,006)$, «Осмисленість життя» $(\mathrm{r}=-0,44, \rho \leq 0,08)$. Отже, чим старшою $є$ людина 3 досвідом участі у бойових діях, тим більших змін зазнають їх смисложиттєві орієнтації, втрачається сенс життя. У військовослужбовців, які не були в зоні ООС, лише в одній із смисложиттєвих орієнтацій спостерігається достовірний обернено пропорційний взаємозв'язок: між показниками віку та локус-контролем - життя $(\mathrm{r}=-0,31, \rho \leq 0,07)$. У військовослужбовців-тиловиків зі збільшенням досвіду військової служби втрачається віра лише в можливість контролю та управління власним життям, у вільне прийняття особистих рішень. На інші якісні трансформації їх ціннісно-смислової сфери вік не впливає.

В результаті виконання всіх етапів дослідження визначено, що смисложиттєві орієнтації військовослужбовців-учасників бойових дій і тих, хто не брав участі в зоні проведення Операції об’єднаних сил, мають певні специфічні відмінності.

\section{Висновки}

1. Ціннісно-смислова сфера як центральне утворення особистості є складною, багаторівневою, динамічною структурою. Вона зазнає змін під впливом кризових чинників, як зовнішньої, так і внутрішньої природи. В кризовій ситуації, зокрема, у зоні проведення бойових дій, відбувається трансформація смислової структури особистості: людина намагається знайти сенс життя, як з метою усвідомлення, інтерпретації здобутого досвіду, так і для продовження власного буття.

2. Участь у бойових діях впливає на розвиток смисложиттєвих орієнтацій особистості - базового утворення іiі ціннісно-смислової сфери. Військовослужбовціучасники бойових дій, на відміну від тих, хто не був у зоні проведення Операції об'єднаних сил, мають порівняно нижчі показники за всіма шкалами смисложиттєвих орієнтацій, окрім задоволеності власною самореалізацією. Ціннісні орієнтації учасників бойових дій загалом є більш диференційованими за їх значущістю та осмисленістю, порівняно з військовослужбовцями, які не перебували в зоні проведення ООС. Достовірно 
більша кількість респондентів з бойовим досвідом, порівняно 3 тими, хто його не має, виявляє полярність в осмисленні життєвих цінностей: дуже глибоко усвідомлює смисложиттєві орієнтації чи втрачає в них сенс.

3. Хронологічний вік більшою мірою негативно впливає на якісні трансформації ціннісно-смислової сфери у досліджуваних з досвідом перебування в Операції об'єднаних сил, порівняно 3 військовослужбовцями-тиловиками. У перших існує достовірний негативний взаємозв'язок між віком і всіма складовими ціннісно-смислової сфери. У респондентів без досвіду участі у бойових діях констатовано достовірний негативний взаємозв'язок лише між показниками віку і локус-контролю - життя.

Гіпотезу дослідження було доведено частково.

Перспективи подальшого дослідження вбачаємо у лонгітюдному вивченні динаміки ціннісно-смислової сфери особистості військовослужбовців-учасників бойових дій.

\section{Література}

1. Ананьев, Б.Г. (2016). Человек как предмет познания. (3-е изд.). Санкт-Петербург : Питер.

2. Василюк, Ф.Е. (1984). Психология переживания (анализ преодоления критических ситуаций). Москва : Изд-во Моск. ун-та.

3. Виговський, С.Є. (2012). Теоретико-методологічні підходи до вивчення смислової сфери особистості. Наука і освіта, 6, 240-243.

4. Выготский, Л.С. (2005). Психология развития человека. Москва : Смысл.

5. Журавльова, Л.П., \& Матюшенко, Т.А. (2009). Вплив емпатії на розвиток ціннісносмислової сфери старшокласників $з$ різною професійною спрямованістю. Наука $i$ освіта, 6, 197-201.

6. Журавльова, Л.П., \& Мужанова, Н.В. (2019). Динаміка ціннісно-смислової сфери учасників субкультур. Психологія:реальність і перспективи: зб. наук. праџь, 12, 66-71.

7. Леонтьев, Д.А. (2007). Психология смысла: природа, строение и динамика смысловой реальности. (3-е изд.). Москва : Смысл.

8. Леонтьев, Д.А. (2000). Тест смысложизненных ориентаџий (СЖО). (2-е изд.). Москва : Смысл.

9. Рубинштейн, С.Л. (2012). Бытие и сознание. Санкт-Петербург : Питер.

10. Ягупов, В.В. (2004). Військова психологія. Київ : Тандем.

11. Atkinson, M. (2003). The Civilizing of Resistance: Straightedge Tattooing. Deviant Behavior, 24(3), 197-220.

12. Dixon, N. (2012). On the Psychology of Military Incompetence. [Electronic resource]. Retrieved from http://combatreform.-org/militaryincompetence.html/

13. Frankl, V. (2004). Man's Search for Meaning: The classic tribute to hope from the Holocaust. London. Sydney. Auckland. Johannesburg : Rider.

14. Freud, S. (2013). Reflections on war and death. [Electronic resource]. Retrieved from http://www.sophiaproject.org/uploads/1/3/9/5/13955288/freud waranddeath/pdf

15. Hogg, M. (2003). «Social Identity: Sociological and Social Psychological Perspectives». Social Psychology Quarterly, 66(1), 97-100.

16. Lawrence, R. (2017). Emotional and Psychological Trauma. [Electronic resource]. Retrieved from https://www.helpguide.org/articles/ptsd-trauma/copingwith-emotional-andpsychological-trauma.html

17. Murray, C. (2002). Armed conflict as a public health problem. BMJ, 324, 346-349.

18. Parks, L., \& Guay R. (2009). Personality, values, and motivation. Personality and Individual Differences, 47, 675-684. 
19. Parks-Leduc, L. (2014). Personality traits and personal values: a meta-analysis. Personality and Social Psychology Review, 1(3), 21-33. https://doi.org/10.1177/1088868314538548

20. Thomas, P. (2006). The Unequal Burden of War: The Effect of Armed Conflict on the Gender Gap in Life Expectancy. International Organization, 60(3), 723-754.

\section{References}

1. Anan'ev, B.G. (2016). Chelovek kak predmet poznanija [Human as a subject of knowledge]. (3rd ed.). Sankt-Peterburg : Piter [in Russian].

2. Vasiljuk, F.E. (1984). Psihologija perezhivanija (analiz preodolenija kriticheskih situacij) [Psychology of experience (analysis of overcoming critical situations)]. Moskva : Izd-vo Mosk. un-ta [in Russian].

3. Vyhovskyi, S.E. (2012). Teoretyko-metodolohichni pidkhody do vyvchennia smyslovoi sfery osobystosti [Theoretical and methodological approaches to the study of the semantic sphere of personality]. Nauka i osvita - Science and education, 6, 240-243 [in Ukrainian].

4. Vygotskij, L.S. (2005). Psihologija razvitija cheloveka [Psychology of human development]. Moskva : Smysl [in Russian].

5. Zhuravlova, L.P., \& Matiushenko, T.A. (2009). Vplyv empatii na rozvytok tsinnisnosmyslovoi sfery starshoklasnykiv $\mathrm{z}$ riznoiu profesiinoiu spriamovanistiu [Influence of empathy on the development of value-meaning sphere of high school students with different professional orientation]. Nauka i osvita-Science and education, 6, 197-201 [in Ukrainian].

6. Zhuravlova, L.P., \& Muzhanova, N.V. (2019). Dynamika tsinnisno-smyslovoi sfery uchasnykiv subkultur [Dynamics of value-semantic sphere of participants of subcultures]. Psykholohiia: realnist i perspektyvy: zb. nauk. prats - Psychology: Reality and Perspectives: Coll. of sciences. papers, 12, 66-71 [in Ukrainian].

7. Leont'ev, D.A. (2007). Psihologija smysla: priroda, stroenie i dinamika smyslovoj real'nosti [Psychology of meaning: nature, structure and dynamics of semantic reality]. (3rd ed.). Moskva : Smysl [in Russian].

8. Leont'ev, D.A. (2000). Test smyslozhiznennyh orientacij (SZhO) [Life Orientation Test (LSS)]. (2nd ed.). Moskva : Smysl [in Russian].

9. Rubinshtejn, S.L. (2012). Bytie i soznanie [Being and consciousness]. Sankt-Peterburh : Piter [in Russian].

10. Yahupov, V.V. (2004). Viiskova psykholohiia [Military Psychology]. Kyiv: Tandem [in Ukrainian].

11. Atkinson, M. (2003). The Civilizing of Resistance: Straightedge Tattooing. Deviant Behavior, 24(3), 197-220.

12. Dixon, N. (2012). On the Psychology of Military Incompetence. [Electronic resource]. Retrieved from http://combatreform.-org/militaryincompetence.html/

13. Frank1, V. (2004). Man's Search for Meaning: The classic tribute to hope from the Holocaust. London. Sydney. Auckland. Johannesburg : Rider.

14. Freud, S. (2013). Reflections on war and death. [Electronic resource]. Retrieved from http://www.sophiaproject.org/uploads/1/3/9/5/13955288/freud_waranddeath/pdf

15. Hogg, M. (2003). «Social Identity: Sociological and Social Psychological Perspectives». Social Psychology Quarterly, 66(1), 97-100.

16. Lawrence, R. (2017). Emotional and Psychological Trauma. [Electronic resource]. Retrieved from https://www.helpguide.org/articles/ptsd-trauma/copingwith-emotional-andpsychological-trauma.html

17. Murray, C. (2002). Armed conflict as a public health problem. BMJ, 324, 346-349.

18. Parks, L., \& Guay, R. (2009). Personality, values, and motivation. Personality and Individual Differences, 47, 675-684.

19. Parks-Leduc, L. (2014). Personality traits and personal values: a meta-analysis. Personality and Social Psychology Review, 1(3), 21-33. https://doi.org/10.1177/1088868314538548

20. Thomas, P. (2006). The Unequal Burden of War: The Effect of Armed Conflict on the Gender Gap in Life Expectancy. International Organization, 60(3), 723-754. 


\title{
PECULIARITIES OF VALUE-SEMANTIC SPHERE OF MILITARY WITH DIFFERENT EXPERIENCE PARTICIPATION IN COMBAT ACTIONS
}

\section{Larysa Zhuravlova}

Doctor of Sciences in Psychology, Professor, Head of the Department of Developmental Psychology and Counseling

Zhytomyr Ivan Franko State University 40, Velyka Berdychivska Str., Zhytomyr, Ukraine, 10008

1pz2008@ukr.net, https://orcid.org/0000-0003-4020-7279

\section{Kateryna Krotiuk}

\section{Postgraduate Student of the Department of Developmental Psychology and Counseling}

Zhytomyr Ivan Franko State University

40, Velyka Berdychivska Str., Zhytomyr, Ukraine, 10008

demkatty28@ukr.net, https://orcid.org/0000-0003-3237-6494

\begin{abstract}
In the present article, the substantiation of actuality and appropriability of research of the valuesemantic sphere of military personal is provided. The main aim of the present study is the research on the impact of combat experience on the value-semantic sphere of military personal. The main modern psychology approaches to addressing the problem of the personality valuesemantic sphere are analyzed, in particular, the changes of the value-semantic sphere as a result of professional duties in the field of military activity. The specificity of combat activity which is connected to life-threatening situations and risk-taking may lead to changes in life values. Therefore, the assumption was made of the destructive influence of the experience of participation in hostilities on the value-semantic sphere of the military. The results of conducted research of life orientations of military personal (the core component of the value-semantic sphere) are presented; comparative analyzes of life orientations of study participants with a different experience of being in the area of the Joint Forces Operation is conducted. The results of the study show no statistically significant differences among life orientations of groups of military personal with and without the combat experience in the Joint Forces Operation, yet they have some specifics. Among the military personal with combat experience, a significantly larger number of people are satisfied with their lives and are able to control it depending on certain circumstances. The negative influence of chronological (ontogenetic) age of the subjects, who have experience of being in Joint Forces Operation, on the quality and indicators of their meaningful life orientations was revealed. The life orientations of combatants are, in general, more differentiated in their significance and meaningfulness than those of weren't in Joint Forces Operation military personnel. Significantly more respondents with combat experience, compared to those who do not have it, exhibit a polarity in the comprehension of life values: they think very deeply about their meaningful life orientations or lose meaning in them.
\end{abstract}

Keywords: value-semantic sphere, values, meanings, military sphere, military activity, meaning of life, Joint Forces Operation. 